\title{
Analysis of molecular features of the ukrainian isolates of HIV-1
}

\author{
N. S. Pukish, A. M. Shcherbinska', N. O. Babij ${ }^{1}$, V. P. Polishchuk
}

National Taras Shevchenko University of Kyiv 64, Volodymyrska Str, Kyiv, Ukraine 01033

${ }^{1}$ Ukrainian center for AIDS prevention, str.Amosova, 5,Kyiv, Ukraine, 03038.

pukishn@ukr.net

\begin{abstract}
Analysis of HIV-1 genome in the region of pol gene was performed by sequencing virus genome using 64 samples of blood from HIV-infected persons. Subtype a HIV-1 revealed to be dominating among investigated samples and a great number of samples belonged to a circulating recombinant forms of HIV-1. Analysis of mutations showed only one mutation connected with development of HIV-1 resistance to antiretroviral treatment. Most samples in-cluded polymorphic substitutions of nucleotides in the virus genome region studied.
\end{abstract}

Keywords: human immunodeficiency virus 1, polymorphic substitutions, resistance mutations, recombinant forms of HIV-1, subtype of HIV-1.

Introduction. Among the all infectious diseases discovered at first in XX century, AIDS not only made essential influence on the human health, but also changed both the view and the attitude of human society towards infectious diseases. Though AIDS had not been registered as a separate disease till 1981 and human immunodeficiency virus (HIV) was determined as its etiological agent only in 1983 [1], this disease caused the lethal termination for 16 millions of people in the whole world and more than 50 millions are HIV-infected nowadays[2].

HIV is characterized by some peculiarities, due to which it is able to evolutionate and change its genome quickly. It can also form the population with high

(C) Institute of molecular biology and genetics NAS of Ukraine, 2009 heterogeneity. The peculiarities are the following: essential level of virus proliferation in vivo, a large amount of the mistakes in virus genome $\left(1 / 10^{4}\right.$ per site) $[3,5]$; high possibility to form HIV-recombinant strains [6].All above mentioned led to a conclusion, that the rate of HIV evolution was one of the highest in nature. The situation became even more complicated because of the usage of antiretroviral preparations (ARVP). The virus is able to select certain mutations leading to the formation of HIV-strains, resistant towards some ARVP [7].These mutations, which are formed or selected as a result of ARVP-therapy, let the virus keep a high rate of the replication process. The clinical importance of these mutations, which appear first (primary mutations) and those which appear later 
Table 1.

The main mutations of HIV-1 genome that are connected with the resistance development.

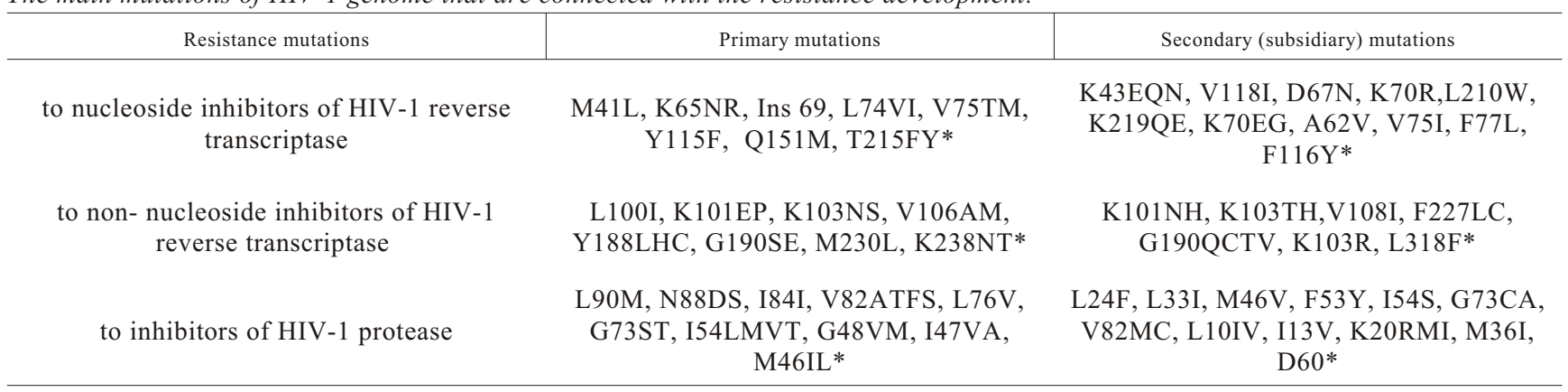

*The data about mutation influence on the resistance development are constantly renewed.

(secondary or subsidiary mutations), has been disputed till now. In common the action of many mentioned mutations is overlapped or complemented by each other (table 1) [8].

Our task was to continue the investigation of HIV peculiarities, which had been studied earlier, namely, to analyze the peculiarities of subtype structure of HIV-1 in the certain Ukrainian regions; to investigate the peculiarities of accumulation of resistance mutations and polymorphic substitutions in HIV genome; and to estimate the level of the primary resistance of HIV in Odessa and Kyiv regions. There is the longest and the widest experience of ARV therapy (since 1990-ies) there as compared with other Ukrainian regions. The study of these problems can help us to determine the molecular peculiarities of HIV-1 that is circulating in Ukraine at the moment.

Materials and methods. The blood samples of 32 HIV-infected patients from Odessa region and 32 HIV-infected patients from Kyiv were investigated. All investigated patients had not been treated before with ARV preparations and the term of their disease did not exceed 1 year. To analyze HIV-1 genome in the samples we used the genomic approach, i.e. the sequencing of HIV-1 pol gene in the sites coding for the proteins of HIV protease(the analysis of the whole protease gene in codons 1-99) and reverse transcriptase(the analyze of two third part of the gene in codons 1-335). The research was done with the use of Viro Seq TM HIV-1 Genotyping system v.2.0,"Abbott", USA. Test-sensitivity was 2x103 copies of HIV RNA per ml. The nucleotide sequencing of HIV-1 included several stages: -isolation of total RNA by precipitation with isopropanol: plasma/serum centrifugation at $25,000 \mathrm{~g}$ for 1 hour at $2-8^{\circ} \mathrm{C}$, addition of lytic buffer with guanidine thiocyanate, addition of $100 \%$ isopropanol, centrifugation at $15,000 \mathrm{~g}$ for $15 \mathrm{~min}$, room temperature, addition of $70 \%$ ethanol, centrifugation, RNA aspiration and its dissolution in the diluent;

-reverse transcription of the obtained RNA into cDNA using Recombinant Murine Leukemia Virus Reverse Transcriptase (MuLV Reverse Transcriptase); -amplification of the target fragment of HIV-1 using AmpliTaq Gold* DNA polymerase and specific primers; 2700 thermal cycler, "Applied biosystem", USA. At this stage the fragment of DNA, 1.8 thousands of base pairs (b.p.) was synthesized. It included the whole protease gene and two third of RT gene of HIV-1;

-purification of the obtained product and determination of its concentration by means of horizontal electrophoresis of nucleic acids in agarose gel using molecular mass marker of $\operatorname{DNA}(2$; $1.2 ; 0.8 \mathrm{ng})$;

-amplification of seven target fragments with Big Dye* terminators, which work in accordance with Sanger principle, 2700 thermal cycler,"Applied biosystems";

-purification of the amplification product with $70 \%$ isopropanol;

-nucleotide sequencing of the obtained DNA product using 3100 genetic analyzer, "Applied biosystems";

-the obtaining of consensus sequence, 1.3 thousands of b.p. with the use of ViroSeq Genotyping 


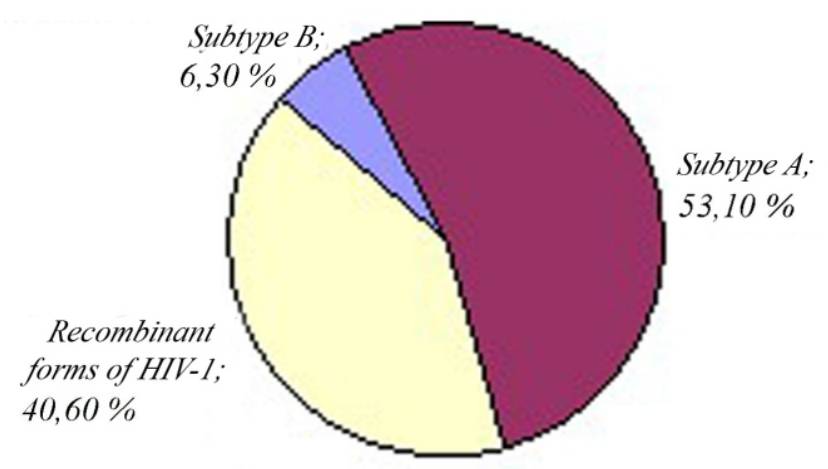

Subtype structure of HIV in the investigated samples.

System Software v.2.6 and its analysis. To define the virus subtype we used international data base of Stanford University (http:/hivdb6.stanford.edu). To make the full analysis of mutations and to define their connection with the resistance development the consensus sequences were analyzed using several different algorithms (algorithms GRADE 4/2007, ANRS_07/2006, HIVDB_4.3.0.2 and REGA_V7.1.1) (http://www.hiv-grade.de/grade/deployed/grade.pl?pr ogram=hivalg) and ViroSeq Genotyping System Software version 2.6. The obtained sequences were compared with the reference-strain of HIV-1 (HXB-2).

Results and discussion. The subtype structure was investigated by sequencing the HIV-1 pol gene of all examined samples. The subtype A of HIV-1 was dominating, it was shown in $53.1 \%$ of the cases meanwhile the subtype B was found only in four samples, that means $6.3 \%$ of the cases (Fig.).

It was interesting, that $40 \%$ of the samples were not "pure" subtypes of HIV-1(Figure). So $23.4 \%$ of the samples belonged to subtype A (defined by the protease gene) and to circulating recombinant form of HIV-1, CRF01_AE (defined by the RT gene). The last one is the most widespread in South-eastern Asia, particularly in Thailand [10]. It was also found four samples $(6.3 \%)$, which belonged to CRF01_AE of HIV-1 and five samples(7.8\%), which belonged to CRF01_AE of HIV-1(defined by the protease gene) and to genotype A (defined by the RT gene).Besides, we found one sample, which belonged to CRF02_AG/H of HIV-1 and another one, which belonged to CRF02_AG/A of HIV-1. The recombinant CRF02_AG of HIV-1 is representative for Western and Central Africa. There are some data, according to which CRF02_AG of HIV-1 migrated to Europe and it is rather widespread in France, Italy, Belgium and Great Britain, meanwhile the subtype H, which is characteristic for Burkina Faso, Mali, Nigeria, Gabon, Congo, migrated to South Europe and Asia [10].

According to the previous investigations, which were carried out in different Ukrainian regions in 2000-2002 the dominating subtype of HIV-1 is subtype A. The situation has not been changed till now $[11,12]$.In our research we have found that only $6.3 \%$ of the whole amount of the investigated samples belonged to subtype $\mathrm{B}$, meanwhile for the samples, that were investigated in 2000-2002 it consisted 30\%. Besides some attention has to be paid to the appearance of circulating recombinant form of HIV-1, especially CRF01_AE, that was not determined in the previous investigations.

So we can make a suggestion, that there was a certain change in the subtype structure of HIV-1 in Ukraine in the last 4-5 years. The quota of subtype B has essentially decreased as compared to 2000-2002 years, but the part of recombinant form has increased substantially.

The nucleotide sequencing of HIV-1 for the determination of resistance mutations showed that only one sample of 64 investigated ones had a virus with the mutation connecting with the high level of resistance development (table 2).In the RT gene of HIV we found amino acid substitution of Val 75 by Met. It can be classified as a primary mutation [13].

The primary or main mutations cause the essential decrease in the virus sensitivity towards certain antiretroviral preparations.

The secondary or subsidiary mutations have minimal (or no) effect on the resistance level, but in the presence of the primary mutations they are able to increase dramatically the virus ability to resistance formation [8].

All other mutations, which were revealed during analysis, belonged to the group of secondary or subsidiary mutations or can be classified as natural polymorphic substitutions.

In one of the investigated samples V179D mutation was found, it was connected with amino acid 
Table 2

The influence of the revealed mutations in the RT gene of HIV-1 on the virus resistance to ARVP.

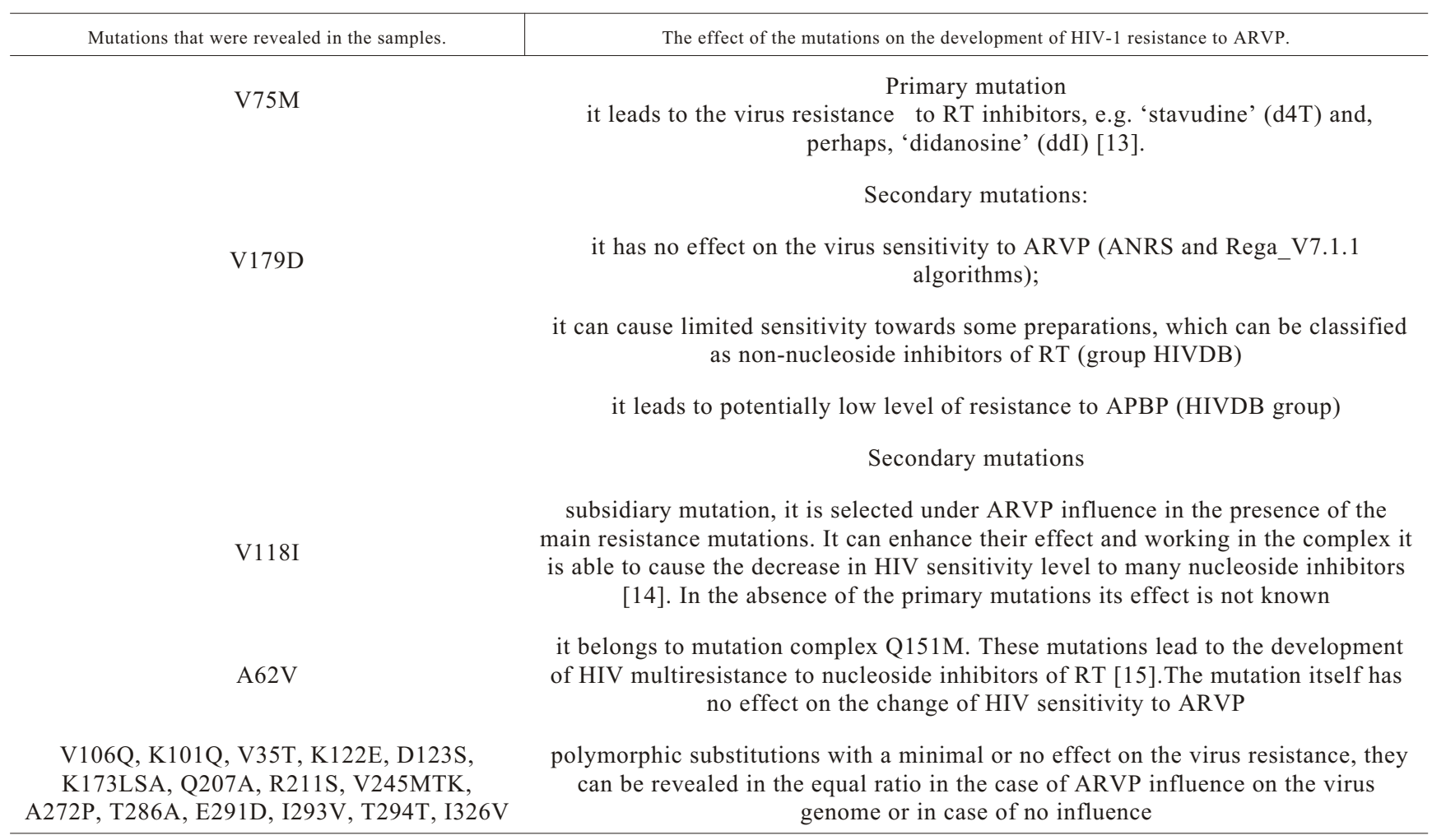

substitution of Val 179 by Asp in the RT gene of HIV. Using the different algorithms, we have discovered that the influence of this mutation on the virus resistance development is ambiguous (table2).

Two samples had V118I mutation in 118 position of the RT gene. Another sample had A62V mutation. The mutation V106Q was also found in one case among the investigated samples and two samples had K101Q mutation in the RT gene (table 1).

Subsidiary mutations in the protease gene, strengthening the action of primary resistance mutations, which were revealed in our investigation, could be divided into two groups: polymorphic (L10I, I13V, K20I, M36I) and non-polymorphic (K43T, $\mathrm{T} 74 \mathrm{~S}$ ), which appeared and were selected as a result of ARV therapy. In the absence of HIV resistance mutations, as it happened in our case, the revealed mutations had no influence on the change of HIV sensitivity towards ARVP $[15,16]$ (table 2).

Besides, we have discovered the row of mutations, which were found in almost all samples in the protease gene and in RT gene as well. They were mainly polymorphic substitutions, i.e. mutations, which appeared and were selected without ARVP influence. These mutations were the following E35D, M36I, $\mathrm{R} 41 \mathrm{~K}$, and $\mathrm{H} 69 \mathrm{~K}, \mathrm{~L} 89 \mathrm{M}$ in protease gene, and V35T, K122E， D123S， K173LSA， Q207A， R211S, V245MTK, A272P, T286A, E291D, I293V, T294T, I326V in the RT gene. It has to be also noticed that nowadays there are many investigations, where the influence of polymorphic substitutions on HIV-1 sensitivity towards ARVP are studied [17] (table 2, table 3).

Thus, in our research concerning the molecular structure of HIV-1, circulating in Ukraine we have shown the dominating role of subtype A of HIV-1. It is necessary to say, that the portion of subtype B of HIV-1 was sharply decreased as compared with the previous years. As it was shown before, the transition from a concentrated epidemic phase of HIV-1 (when epidemic is limited by the certain risk group i.e. injected drug users) in the certain territory to a generalized phase 
Table 3.

The influence of mutations in the pol gene of HIV-1 on the virus resistance to ARVP.

Mutations revealed in the samples

L10I, I13V, K20I, M36I

K43T, T74S
The effect of the mutations on the development of HIV-1 resistance to ARVP

Subsidiary polymorphic substitutions

Subsidiary non- polymorphic substitutions

Have no effect on HIV-1 resistance development to ARVP in the absence of primary mutations

(when epidemic exceeds the bounds of the group) was accompanied by the replacement of subtype B by other non-B subtypes of HIV [18]. Our investigations also proved this observation. Besides, it is noteworthy that the recombinant circulating isoforms of HIV-1 compose a considerable part that had not been observed earlier.

We revealed subsidiary and polymorphic nucleotide substitutions in the investigated samples. The connection of these mutations with the resistance development is still unclear. Because of among the investigated samples it was only one, containing the virus with the resistance to ARVP, we may suggest that at this stage of the epidemic development there is only beginning of the formation of HIV-1 resistant strains in Ukraine. However, the transmission of these viruses to the patients, who were not treated by ARVP, is at the low level. The spreading of the resistant strains can be limited by the following: a period of ARV-treatment in the certain territory, the therapy usage for HIV-positive patients, peculiarities of ARVP-treatment and efficiency of prophylaxis. As it was known the highest spreading of primary resistance towards ARVP was observed in Great Britain (14\%) as compared with the USA (8-10\%), France $(9 \%)$ and other European countries [9]. ARVP were first used for the treatment of HIV-infected patients in the USA and western-European countries that led to the quick development of the resistant strains there.

All above mentioned proved the expediency and necessity of annual monitoring on the development of HIV-1 resistance mutations and their spreading among the population.

\section{Н. С. Пукіш, А. М. Щербінська, Н. О. Бабій, В. П. Поліщук}

Аналіз молекулярних особливостей українських ізолятів ВІЛ-1

Резюме

Проведено аналіз геному ВІЛ-1 у ділянці гена pol 64 зразків крові ВІЛ-інфікованих осіб з використанням методу визначення нуклеотидної послідовності нуклеїнової кислоти. Встановлено, щуо домінуючим серед досліджених зразків ВІЛ-1 виявився субтип $A$, а значна кількість зразків належить до циркулюючих рекомбінантних форм ВІЛ-1. За результатами аналізу наявних мутаиій знайдено лише одну, пов'язану з розвитком резистентності ВІЛ-1 до антиретровірусних препаратів. У більшості зразків визначено поліморфічні заміни нуклеотидів у досліджуваній ділянці геному ВІЛ-1.

Ключові слова: вірус імунодефіциту людини-1, поліморфічні заміни, мутації резистентності, рекомбінантні форми ВІЛ-1, субтип ВІЛ-1.

Н. С. Пукиш, А. М. Щербинская, Н. О. Бабий, В. П. Полищук

Анализ молекулярных особенностей украинских изолятов ВИЧ-1

Резюме

Проведен анализ генома ВИЧ-1 в области гена pol 64 образиов крови ВИЧ-инфицированных лии с использованием метода определения нуклеотидной последовательности нуклеиновой кислоты. Установлено, что доминирующим среди исследованных образцов оказался субтип $A$, а значительное количество изолятов относится к ииркулирующим рекомбинантным формам ВИЧ-1. В результате анализа обнаружена одна мутация, связанная с развитием резистентности ВИЧ-1 к антиретровирусным препаратам. В большинстве образиов выявлены полиморфические изменения нуклеотидов в исследованном участке генома ВИЧ-1.

Ключевые слова: вирус иммунодефицита человека-1, полиморфические изменения, мутации резистентности, рекомбинантные формы ВИЧ-1, субтип ВИЧ-1. 


\section{REFERENCES}

1. Gallo R. C., MontagnierL. The discovery of HIV as the cause of AIDS // New Engl. J. Med.-2003.-349, N 24.-P. 22832285.

2. UNAIDS. AIDS Epidemic Update: December 2007.

3. Requejo $H$. Worldwide molecular epidemiology of HIV // Rev. Saude Publica.-2006.-40, N 2.-P. 331-345.

4. Peters M., Sharp R. M. Genetic diversity of HIV-1: the moving target // AIDS.-2000.-14, № 3.-P. 129-140.

5. McCutchan F. E. Understanding the genetic diversity of HIV$1 / /$ AIDS.-2000.-14, № 3.-P. 31-44.

6. Barlet J., Galant J. Clinical aspects of HIV-infection.-M.: EnRus, 2007.-557 p.

7. de Ronde A., van Dooren M., van der Hoek L., Bouwhuis D., de Rooij E., van Gemen B., de Boer R., Goudsmit J. Esteblishment of new transmissible and drug sensitive human immunodeficiency virus type 1 wild types due to transmission of nucleoside analogue-resistant virus // J. Virol.-2001.-75.P. 595-602.

8. Clavel F., Hance A. HIV drug resistance // New Engl. J. Med.-2004.-350, N 10.-P. 1023-1035.

9. Vijver D., Wensing A., Boucher C. The epidemiology of transmission of drug resistant HIV-1. Sequence compendium 2006/2007.-Los Alamos, 2007.-P. 17-36.

10. Tatt I., Barlow K., Nicoll A., Clewley J. The public health significance of HIV-1 subtypes // AIDS.-2001.-15, N 24.P. 59-71.

11. Saad M., Shcherbinskaya A., Nadai Y., Kruglov Y., Antonenko S., Lyullchuk M., Kravchenko O., Earhart K., Sanchez J., Birx D., Carr J. Molecular epidemiology of HIV type 1 in Ukraine: birthplace of an epidemic // AIDS Res. and Hum. Retroviruses.-2006.-22, N 8.-P. 709-714.

12. Nabatov A., Kravchenko O., Lyulchuk M., Shcherbinskaya A., Lukashov V. Simultaneous introduction of HIV type 1 subtype A and B viruses into injecting drug users in southern Ukraine at the beginning of the epidemic in the former Soviet Union // AIDS Res. and Hum. Retroviruses.- 2002.-18, N 12.-P. 891-895.

13. Johnson V., Vezinet F., Clotet B., Gunthart H., Kuritzkes D., Pillay D., Shapiro J., Richman D. Update of drug resistance mutations in HIV-1: 2007 // Top. HIV Med.-2007.-15, N 4.P. 119-125.

14. Johnson V., Brun-Vezinet F., Cloet B., Gunthart H., Kuritzkes D., Pillay D., Shapiro J., Richman D. Update of Drug Resistance Mutations in HIV-1: 2006 // Top. HIV Med.-2006.-14, N 3.-P. 125-130.

15. Shafer R., Rhee S., Pillay D., Miller V., Sandstrom P., Shapiro J., Kuritzkes D., Bennet D. HIV-1 protease and reverse transcriptase mutations for drug resistance surveillance // AIDS.-2007.-21.-P. 215-223.

16. $H I V$ drug resistance mutations by drug class (January 28 , 2008) - http://hivdb.standford.edu.

17. Sukasem C., Churdboonchart V., Sukeepaisarncharoen $W$. , Piroj W., Inwisai T., Tiensuwan M., Chantratita W. Genotypic resistance profiles in antiretroviral-naVve HIV-1 infections before and after initiation of first-line HAART: impact of polymorphism on resistance to therapy // Int. J. Antimicrob. Agents.-2008.-31, N 3.-P. 277-281.

18. Hu D., Subbarao S., Vanichseni S., Mock P., Ramos A., Nguyen L., Chaowanachan T., Griensven F., Choopanya K., Mastro T., Tappero J. Frequency of HIV-1 dual subtype infections, including intersubtype infections, among injection drug users in Bangkok, Thailand // AIDS.-2001.-19, N 3.-P. 303-308.
UDC 587.828

Received 03.09.08 